\title{
Conflicts over water and land use on the coastline of the region of Valencia: agriculture versus the urban-tourist city
}

\author{
M. Hernández Hernández, A. M. Rico Amorós \\ \& C. Juárez Sánchez R. \\ Institute of Geography, University of Alicante, Spain
}

\begin{abstract}
During the second half of the last century and the first years of this century, the Region of Valencia has experienced major economic growth. The processes of urbanisation, industrialisation and tourism have led to $77 \%$ of the region's population living on the coast, with significant repercussions on land and water resources. As a result of ecological factors and historical land occupation, the region's main irrigated areas are in the coastal plains. Urban and tourist expansion in these areas will bring about a major reduction in irrigated land, not only in areas of historic irrigated farmland, but also now in new areas. This competition between the two also affects water resources. The sharp increase in water consumption is the result of, among other reasons, the qualitative and quantitative changes that have occurred due to different demands. The dominant dynamic can be expressed as a drop in agricultural consumption and an increase in urban use. This paper aims to analyse the causes of the conflicts that arise over land and water resources between farming and urban and tourist activities, with particular emphasis on certain factors that have become accentuated in the past decade. This analysis includes an explanation of the actions taken to cope with these growing demands, particularly the initiatives aimed at minimising the conflicts that arise between farming and urban and tourist activities.
\end{abstract}

Keywords: competition, water demand, irrigated land, urban and tourist uses, land zoning, Region of Valencia. 


\section{Introduction}

For various climatic, hydrographical and hydrogeological reasons, the Region of Valencia in Spain suffers from a natural shortage of freshwater resources. Leeward of the general atmospheric circulation to the west, rainfall is not only minimal but also very irregular, with very little effectiveness because of the intensity with which it falls, combined with considerable potential evapotranspiration and dry summers. This leads to a natural aridity in the region, with annual rainfall levels that rarely exceed $350 \mathrm{~mm}$. However, the area has many advantages for fruit and vegetable export crops and for tourism, due to the available warmth and light, with annual averages of $16-18^{\circ} \mathrm{C}$, and very mild winters, with average temperatures of more than $10^{\circ} \mathrm{C}$. On a regional level, a precarious balance exists between water demand $\left(3,667 \mathrm{hm}^{3}\right.$ per year) and resources $\left(3,467 \mathrm{hm}^{3} /\right.$ year). This supply and demand is also unevenly spread, with three systems producing a surplus of $223 \mathrm{hm}^{3}$ per year, and eight systems registering a deficit of $439 \mathrm{hm}^{3}$ per year. Whereas the Júcar and Turia rivers provide the province of Valencia with sufficient freshwater resources, the provinces of Castellón and Alicante have very serious deficits, resulting in the overexploitation of a number of aquifers.

Another defining feature of water use in the Region of Valencia is its social and economic significance. Agricultural and urban/tourist demands are of major strategic value for the national balance of payments. In 2008, the Region of Valencia generated $11.5 \%$ of Spain's GDP and $13 \%$ of the value of its exports. According to the National Institute of Statistics [1], the provinces of Valencia and Alicante were in third and fourth place in Spain behind the provinces of Madrid and Barcelona in terms of jobs created, and in third and sixth place, respectively, for the gross domestic product generated. According to data from the Generalitat Valenciana (the regional government) [2], Spain exported $€ 7,388$ million of fruit and vegetables to European markets in 2007, and this is Spain's leading region for agricultural produce exports, calculated at more than $€ 2,500$ million from citrus fruits and vegetables. Irrigated croplands in the Region of Valencia are profitable, of great social significance and highly efficient in terms of water consumption, particularly when compared with extensive irrigation systems in inland Spain. According to Gil Olcina and Rico Amorós [3], irrigated maize crops farmed inland in the Iberian Peninsula yield $€ 0.20 / \mathrm{m}^{3}$, compared with $€ 1.60 / \mathrm{m}^{3}$ for 'oronules' mandarins, or almost $€ 20 / \mathrm{m}^{3}$ for modified-cycle vegetables such as the 'California' pepper. The process of developing and consolidating a residential and tourist-based infrastructure since the mid-20th century is another hugely important element in both land-related and socioeconomic terms. With 22.9 million tourists in 2008, the Region of Valencia was Spain's third most-visited region, generating $€ 13,502$ million $(13.2 \%$ of the regional GDP, and $12.1 \%$ of the national GDP), making it the region where tourism has made the largest contribution to the GDP of Spain. 


\section{Competition for water and conflict between agricultural and urban-tourist uses}

During the second half of the 20th century, water consumption increased due to qualitative and quantitative changes resulting from different demands. This process has increased the vulnerability of supply systems to periods of drought, as well as producing fierce competition over the use of both land and water between economic interests (farming and tourism) and environmental considerations (wetlands).

In urban areas, the number of users and inhabitants connected to the mains supply for drinking water rose significantly throughout the 20 th century and into the 21 st. Thus, whereas in 1910 there were 1,704,127 inhabitants, by 2008 the population had increased to 5,029,601, without counting the seasonal population of holidaymakers and tourists. In 1910, average daily water consumption was 10 litres per inhabitant, making for a total demand of $6,215,950 \mathrm{~m}^{3}$. In 2008 , the net average demand per inhabitant was around 200 litres per day, though in many towns in the south of Alicante province (Guardamar, Torrevieja, Santa Pola, etc.), this figure ranges from 150 to 175 litres per day, according to Juárez [4]. This is equivalent to an annual consumption of around $367 \mathrm{hm}^{3}$. Major qualitative changes have also occurred in water used for agriculture. Cereals and olives were associated with certain vegetables and tubers on irrigated farmland in the region up to the end of the 19th century, when they were gradually replaced mainly by citrus trees and vegetables with greater water requirements. From the 1960s onwards, historical systems that used gravity to irrigate land from rivers and springs were replaced by other uptake systems using powerful pumps to extract water from rivers and aquifers. Work was also completed on the water transfer projects between the Tajo and Segura rivers (1979) and between the Júcar and Turia rivers (1978), both of which were proposed in the first National Hydraulic Works Plan (1933). This made it possible to draw and raise water from land far from the rivers' flood plains, allowing irrigation to spread to other areas. In 1904, there were 182,826 hectares of irrigated farmland in the region, with a demand of $1,175 \mathrm{hm}^{3}$. In 2007, these figures had risen to 340,298 ha and a potential demand of $2,466 \mathrm{hm}^{3}$. Although local irrigation now covers more than 200,000 ha, water consumption has increased due not only to the spread of irrigated land, but also because of higher use: the average of $5,000 \mathrm{~m}^{3} /$ ha/year has risen to around $7,000 \mathrm{~m}^{3} /$ ha/year, due to the greater water needs of crops such as citrus fruits.

\subsection{The drop in irrigated farmland in the region}

Because of ecological factors and historical farming habits, the coastal plains, flood plains and inland valleys are where most irrigated land is situated, leading to stiff competition with activities such as tourism. In 2007, there were 340,298 ha of irrigated land in the region, although water availability and crop profitability lead to notable differences between the region's three provinces (Table 1). The expansion of irrigated land, which came to an end in the late 
1990s, was spearheaded by a range of crops for export such as citrus fruits (which in many areas are now a monoculture), vegetables and table grapes. However, during the past decade (1998-2007) there has been a change in trend, with around 42,000 ha being abandoned, together with a further 37,053 ha lying fallow and no longer irrigated. This process is felt most strongly in Alicante, where irrigated land (which in 1998 meant 35\% of all land) has dropped to around 32,000 ha.

Table 1: Evolution of irrigable land and farming-related water demand in the region of Valencia.

\begin{tabular}{||c|c|c|c|c|c|c|}
\hline \multirow{2}{*}{} & \multicolumn{2}{|c|}{1998} & \multicolumn{2}{c|}{2007} & \multicolumn{2}{c|}{ Evolution 2007-1998 } \\
\cline { 2 - 7 } & $\begin{array}{c}\text { Surface } \\
\text { area (ha) })\end{array}$ & $\begin{array}{c}\text { Demand } \\
\left(\mathrm{hm}^{3}\right)\end{array}$ & $\begin{array}{c}\text { Surface } \\
\text { area (ha) })\end{array}$ & $\begin{array}{c}\text { Demand } \\
\left(\mathrm{hm}^{3}\right)\end{array}$ & $\begin{array}{c}\text { Surface } \\
\text { area (ha) }\end{array}$ & $\begin{array}{c}\text { Demand } \\
\left(\mathrm{hm}^{3}\right)\end{array}$ \\
\hline R. of Valencia & $\mathbf{3 8 2 , 3 5 8}$ & $\mathbf{2 , 7 0 4}$ & $\mathbf{3 4 0 , 2 9 8}$ & $\mathbf{2 , 4 6 6}$ & $\mathbf{- 4 2 , 0 6 0}$ & $\mathbf{- 2 3 7}$ \\
\hline Alicante & 138,444 & 692 & 106,373 & 531 & $-32,071$ & -160 \\
\hline Castellón & 59,350 & 445 & 53,454 & 401 & $-5,896$ & -44 \\
\hline Valencia & 184,358 & 1,567 & 180,471 & 1,534 & $-3,887$ & -33 \\
\hline
\end{tabular}

In terms of irrigation and water consumption, there is one element that all the region's areas have in common: the destruction of farmland for urban and industrial development, both on the coast and inland, coupled with the structural factors that define the sector, such as the fragmented nature of the plot system, the ageing of assets, weaknesses in the marketing channels, the lack of freshwater resources and the impact of droughts (particularly in the province of Alicante), all of which make farming particularly difficult. In the three provinces, the traditionally irrigated farmland in coastal towns has shrunk in recent years due to the processes of urbanisation that continue to spread into the hinterland (Navalón) [5], as is the case in Gandía (Valencia) and Torrevieja (Alicante), which between 1985 and 2000 lost $25 \%$ and $50 \%$ of their irrigated land, respectively. Other towns, such as Castellón, Valencia, Alicante and Elche, among others, have also lost areas of irrigated land that dated back to Roman or medieval times, due to their proximity to rapidly expanding metropolitan areas. An extreme example of this is the Huerta de Valencia, an area of around 15,000 ha where urban sprawl exerts such pressure on traditional irrigated farmland, particularly at the southern and western ends, that more than $75 \%$ of it has been lost to development.

The loss of irrigated land has led to a significant drop in the demand for water for farming use. This drop in potential demand is calculated at around $237 \mathrm{hm}^{3}$ for the period between 1998 and 2007, together with a further $203 \mathrm{hm}^{3}$ from fallow land that is no longer irrigated. Falls in demand of $1-5 \mathrm{hm}^{3}$ are typical for most of the coastal and pre-coastal towns, reaching almost $10 \mathrm{hm}^{3}$ in the metropolitan area of Valencia due to the greater intensity of the development process on formerly irrigated land. In towns such as Llíria and Elche, the decrease is of more than $25 \mathrm{hm}^{3} /$ year, a clear indication of the shrinkage of irrigated land due to the spread of residential, industrial, service-based and 
transport-related infrastructure in the metropolitan areas of Valencia and Alicante-Elche (Figure 1).

As well as competition over land use, there are also conflicts between agricultural demands and urban and tourist-based needs for better-quality resources and a guaranteed supply. This competition is clearly one of unequal strengths, as the Water Law of 1985 grants priority of use (Art. 60, TRLA) to urban supplies over agricultural use. Thus, during periods of drought in recent decades, urban supply has always been guaranteed, with irrigated farmland suffering huge economic losses. It is worth noting that in the areas of Alicante irrigated by the Tajo-Segura aqueduct, around $€ 360$ million and 18,000 jobs were lost in 2005, together with around 20,000 ha of citrus fruits and vegetable crops, but supply to the 2.5 million inhabitants in Murcia and Alicante was guaranteed. The competition for water usage is clear, but the same applies to how land is taken over for urban development. Many farmers have opted not to continue in agriculture, but not just because of water shortages or the loss in profitability of their land; another decisive factor is the dramatic rise in sale prices for arable land, in the hope that it can be reclassified for urban development, as a result of which prices in some coastal towns have exceeded $€ 600,000 /$ ha. The combined effect is felt in how water needs have evolved, with

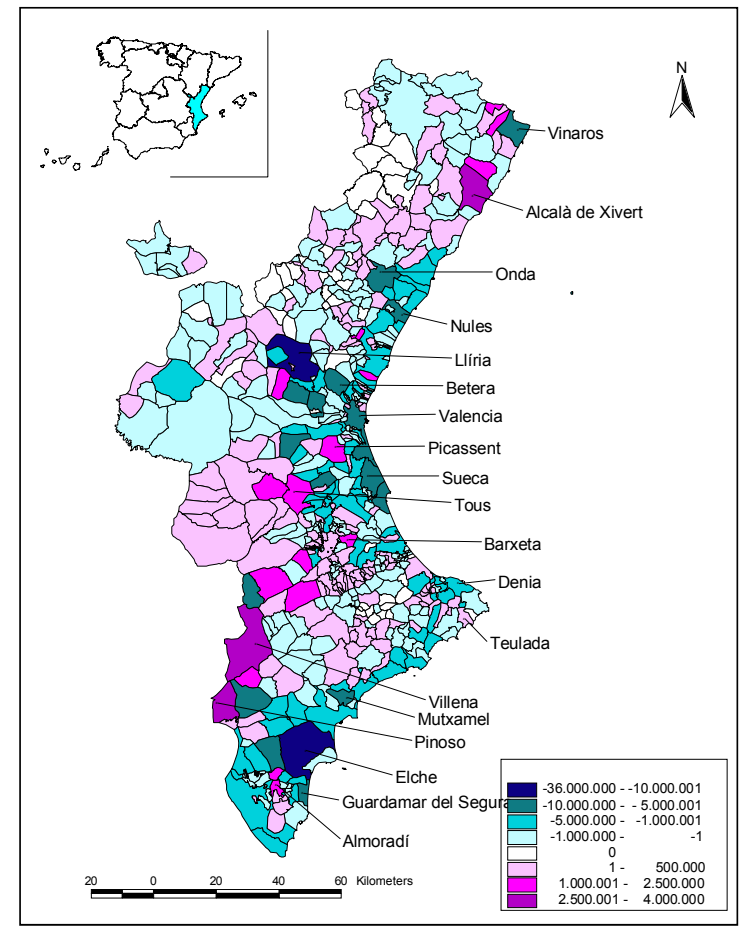

Figure 1: $\quad$ Evolution of water use $\left(\mathrm{m}^{3}\right)$ by irrigation (1998-2003). 
a drop in agricultural requirements and a growing demand for urban and tourismbased supply. From 2000 to 2006, 28,000 ha of irrigated land were lost, whereas 653,000 housing units were built, of which 166,000 were single-family homes with high levels of water usage (Rico \& Hernández) [6].

Competition for water does not always lead to confrontation, with some users losing out to others. The scarcity of resources has led to agreements between communities of irrigators and companies that supply drinking water. Examples of water-use rights being granted make the Region of Valencia a pioneer in Spain in establishing agreements between farmers and drinking water suppliers. Residential and tourism-based development in metropolitan areas would not be possible without the agreements that exist between water supplier Aguas Municipalizadas de Alicante and the communities of irrigators in Caudete and Villena for the use of quality subterranean water. Another interesting example is the hydraulic system built in 1980 by IRYDA in Medio Vinalopó and Campo de Alicante, by which water is pumped from the Alicante treatment plant to farmland in Agost and Monforte del Cid, with pumping costs of around $€ 0.18 / \mathrm{m}^{3}$, paid for in full by the farmers. Irrigators in the Canal del Bajo Algar area, in the Marina Baja, benefit from a much more favourable agreement, thanks to a system that reuses waste water. The irrigators allow clean water to be supplied to the Marina Baja Water Consortium, which includes the tourist resorts of Benidorm, Villajoyosa, Polop, La Nucía and Alfaz del Pi, in exchange for waste water from the Benidorm treatment plant. Such systems are now widespread in other districts, including Vinalopó and Bajo Segura, making Alicante the leading province in Spain in initiatives to reuse waste water.

\subsection{The intensification of urban and tourism-based water requirements}

The predominance of "sun and sea" package tourism means a high concentration of tourist activity in coastal and pre-coastal towns. According to the Valencia Tourist Board [8], in 2008 there were 325,405 accommodation places, of which 127,695 were in hotels, located mainly on the Alicante coast and Benidorm in particular, which accounts for $50 \%$ of availability. Added to this type of accommodation are unregulated residential homes and apartments, which according to Vera et al [8] make up around 2.2 million places, or $20 \%$ of the total for tourism-based accommodation in Spain. This is the dominant type of accommodation, and is indicative of the importance of residential tourism and the property sector in the Region of Valencia.

The region became fully consolidated by 1995 , with tourist numbers and hotel places increasing further still between 2000 and 2005, with the creation of 28,880 places compared with the 8,500 created during the whole of the 1990s. However, the most spectacular figures come from the increase in housing. Between the 1991 and 2001 censuses, the total number of homes in the region grew from 2,094,033 to 2,547,775, an increase of 453,742 (Table 2). Data from the Ministry of Development [9] on official certificates of completion confirm the rise in new homes built in the Region of Valencia, particularly in the provinces of Valencia and Alicante, with around 400,000 new homes built 
Table 2: $\quad$ Evolution of housing built in the region of Valencia.

\begin{tabular}{||c|c|c|c|c|c||}
\hline & $\begin{array}{c}\text { Population } \\
(2001)\end{array}$ & $\begin{array}{c}\text { Population } \\
2008\end{array}$ & $\begin{array}{c}\text { Total } \\
\text { homes } \\
(2001)\end{array}$ & $\begin{array}{c}\text { No. new } \\
\text { homes built } \\
1993-02\end{array}$ & $\begin{array}{c}\text { No. new } \\
\text { homes built } \\
2003-2008\end{array}$ \\
\hline R. of Valencia & $\mathbf{4 , 1 6 6 2 , 7 7 6}$ & $\mathbf{5 , 0 2 9 , 6 0 2}$ & $\mathbf{2 , 5 4 7 , 7 7 5}$ & $\mathbf{5 1 6 , 4 8 3}$ & $\mathbf{4 8 0 , 0 0 4}$ \\
\hline Alicante & $1,461,925$ & $1.891,477$ & $1,004,188$ & 267,803 & 206,295 \\
Castellón & 484,566 & 594,915 & 325,689 & 64,277 & 169,420 \\
Valencia & $2,216,285$ & $2,543,209$ & $1,217,898$ & 184,403 & 104,289 \\
\hline
\end{tabular}

between 1993 and 2002, particularly on the coastline itself, where development has been frenetic. Analysis of this process on a municipal scale gives even more spectacular figures.

During the 1990s, six of the ten towns with the highest numbers of homes recorded in the 1991 population census are on the Mediterranean coast, the top two places going to Torrevieja and Guardamar del Segura (in the south of Alicante province). In the 1993-2002 period, Torrevieja was in second place nationally, behind Madrid and ahead of Barcelona, in the total number of official certificates of completion, with 43,268 new homes built. This trend has continued up to 2008 , coinciding with the outbreak of the property crisis. Data from the Ministry of Housing indicate that between 2003 and 2008, work began on 438,875 new homes in the Region of Valencia [10]. This process is not exclusive to the Valencia coastline, but rather is largely characteristic of Spain's Mediterranean coast in general. From 2002 to 2008, 139,085 new homes were built in Almería, 368,129 in Málaga, 322,470 in Murcia and 114,073 in Girona. With 839,257 homes built from 1993 to 2008, the Region of Valencia was the third in Spain in new homes built. Most of these are secondary homes for seasonal use, which in 2001 accounted for $22 \%$ of all homes, compared with $15 \%$ in 1991 . These figures can be much higher in coastal and pre-coastal towns, and in places can surpass $50 \%$. There are various reasons to explain the magnitude of this property boom: a) the affluence of tourists, residents and holidaymakers from Central and Western Europe, together with the influx of traditional clients from the European Union and the rest of Spain (Basque Country, Castile-León, Madrid and Castile-La Mancha); b) the Town-Planning Regulatory Law that came into effect in the Region of Valencia in 1994 also made it easier for town-planning projects to be processed to completion; c) local authorities granted more construction licences to increase rates revenues, which led to municipal planning being reviewed to create land suitable for development.

The spread of residential buildings has had notable repercussions for water requirements. Drinking water consumption has increased slightly, whereas the demand for irrigation water has dropped due to the abandonment of land, and conflicts over water use have heightened, particularly during periods of drought. However, according to various estimates [11], rises in drinking water consumption as a result of increased hotel accommodation is actually of little significance. Estimations based on billing data indicate an increase in 
consumption of no more than $10 \mathrm{hm}^{3}$ per year. Repercussions in employment and income, however, are striking. In recent years, Benidorm (which has one of the highest numbers of accommodation places in the region), has needed $12 \mathrm{hm}^{3}$ per year to meet the needs, among other demands, of its 68,981 places (2008), which generate revenues of more than $€ 500$ million. Added to this active supply of accommodation during a large part of the year (average occupancy levels are around $92 \%$ ) and a capacity to generate income that on average can exceed $€ 60$ per day per person in accommodation, is a wide range of complementary services - the town has around 370 restaurants, more than 250 cafés and 2,200 shops.

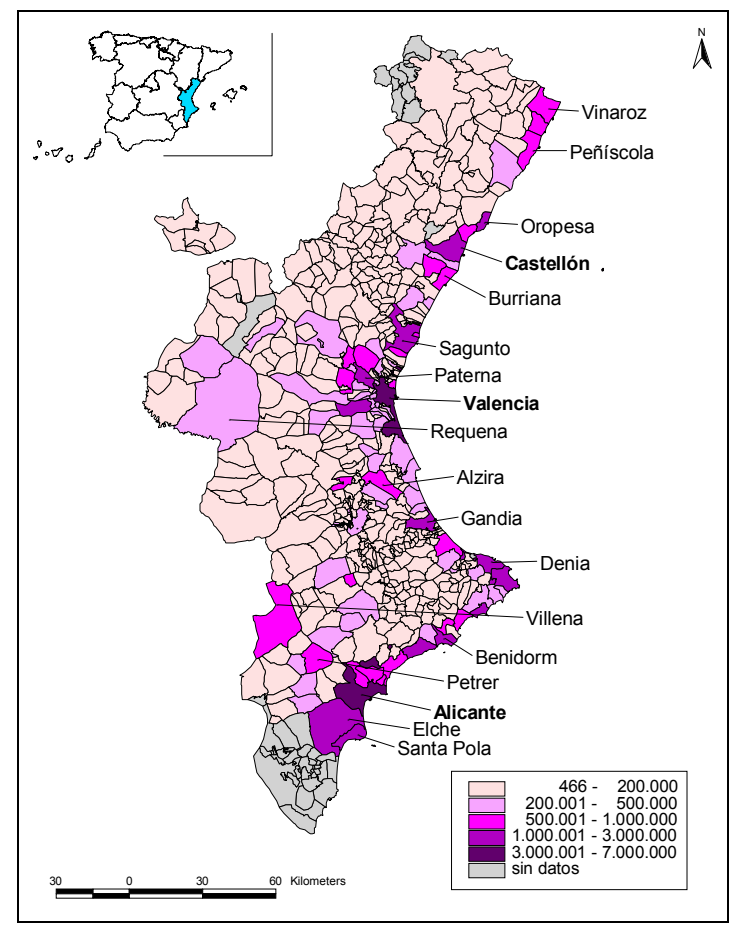

Figure 2: Increase in water consumption associated with the building of homes (1998-2003).

Residential accommodation is also highly important, with a demand of 120 $\mathrm{hm}^{3}$ per year, mainly in July and August, a figure that increases by a further 30 $\mathrm{hm}^{3}$ per year if the water used by golf courses and water parks is also added. The property boom of recent decades has led to increased requirements for drinking water in the region. Between 1993 and 2002, demand increased by around 79 $\mathrm{hm}^{3}$, without including the towns belonging to the Segura River Basin (Figure 3), and by a similar amount $\left(80 \mathrm{hm}^{3}\right)$ between 2003 and 2008 . These volumes of consumption, which are the result of various estimations [11], need to be reduced by around $30 \%$, taking into account variables such as per capita consumption of less than 200 1/inhabitant/day, and the periods of occupancy of second homes in 
the summer and at holiday times. Coastal and pre-coastal towns have produced the highest increases, as a result of the intense process of urbanisation.

At the municipal level, the notable locations are the three provincial capitals and Elche, with increases in demand ranging from $6.6 \mathrm{hm}^{3}$ in Valencia to 2.3 $\mathrm{hm}^{3}$ in Castellón. This is related to the demand resulting from the size of their populations and the need for new buildings. Other coastal and pre-coastal towns with high residential accommodation figures such as Denia and Santa Pola have also recorded notable increases in consumption by around $2 \mathrm{hm}^{3}$, a similar figure to that registered in cities such as Castellón, with a considerably higher population. According to the 2001 population census, Castellón has 147,667 inhabitants, compared with 19,782 in Santa Pola and 33,342 in Denia. The most spectacular increases in consumption, however, have been recorded in the towns covered by the Segura Basin Water Authority, such as Torrevieja and Orihuela, with 8 and $7 \mathrm{hm}^{3}$, respectively, increases that surpass even those of Valencia. According to actual consumption data provided by the Taibilla Canals Association, Torrevieja has increased consumption from $2.5 \mathrm{hm}^{3}$ in 1984 to 5.6 $\mathrm{hm}^{3}$ in 1990 , and to $9.6 \mathrm{hm}^{3}$ in 2008 . As well as exerting major pressure on water resources, the extent of the property boom has also produced intense debate about territorial, environmental and socioeconomic sustainability [12].

\section{Conclusions: is it possible to square the circle between land zoning, water shortage, competition between uses and the intensification of urban and tourism-based requirements?}

The loss of irrigated land and urban sprawl illustrate the fierce competition regarding how land and water are used on the coast of the Region of Valencia by agriculture and tourism. It is worth noting that the growth and spread of tourism on the region's coast has been a huge incentive for different administrations over the decades, though without providing any definitive solutions to drinking water shortages and effective drought management. A decisive matter is how much consideration freshwater resources are accorded in the various land zoning laws.

Article 60 of the Consolidated Text of the Water Law in Spain states that water concessions must give priority to supplying populations over other needs, such as irrigation, industrial supply, aquaculture, recreational uses and shipping. Articles 122 to 125 establish the necessary procedures for the concession of drinking water resources. Water shortages do not feature as a factor conditioning how such rights are granted (Blanquer) [13]. Thus, in tourist resorts and areas of urban sprawl, no land zoning provisions placed water availability before the viability of urban developments. In the Region of Valencia, and particularly along its coastline, towns resorted to development plans as a conventional strategy to meet the demands of land certified for residential purposes, which has led to a planning model based on excess (Burriel) [14]. Law 6/1994, Regulating Town Planning Activity (LRAU), fulfilled the purpose of regulating how planning is performed and implemented, but made no reference to territorial strategies or models of growth. Article 19.C provided incentives for planning models in low- and medium-density resorts that could not be more inappropriate 
for areas where water is scarce. These are the very regulations that allowed the 1992-2008 property boom to occur in the first place.

In recent years, however, major advances have been made in the Region of Valencia as to how water resources are considered in various land zoning laws. This was preceded by notable changes in the Water Law itself, as set forth in Law 46/1999 and the Consolidated Text enacted by means of Royal Decree 1/2001. On a national scale, Law 4/2004, on Land Zoning and Landscape Protection in the Region of Valencia, includes a specific chapter on sustainable development, with several articles devoted to water resources as a fundamental criterion of land zoning management. Thus, water resources must be considered within land zoning and town planning management provisions in order to ensure an efficient and sustainable use (articles 17 and 19) that preserves the quality of existing bodies of water (art. 18). However, the most notable qualitative step that this law makes is that new uses for land that mean increased water consumption require a favourable report from the basin authority to guarantee availability and to ensure that other uses that enjoy recognised rights are not affected (art. 19.2). The impact on the land of these articles is clear, as the different planning provisions should not allow for demand to grow in systems where supply is precarious, though they do leave open the possibility, ensuring the availability of water from unconventional sources or the reuse of waste water. The "Defining directives for the strategy of urban evolution and land occupation" section of Law 16/2005 on Town Planning in the Region of Valencia, which replaces the LRAU, broadened these provisions by which the various planning instruments must establish the potential limit of water supply depending on the capacity of the water bodies, although again it leaves open the possibility of resorting to desalination for new planning developments. All these elements are broadened further in Decree 67/2006, from 12 May, by the regional government, approving the Regulations on Urban Zoning and Land Management (Articles 38 to 42), particularly in matters of saving water, reusing waste water and the use of desalinated water.

The implementation of both regulations has had surprising consequences. In 2005 and 2006, they led to a flood of submissions to develop Integrated Action Plans (IAPs) as a result of the advantages provided by the LRAU. To prevent the restrictions of the new laws in the Region of Valencia, many local councils initiated reviews of their urban development plans; analysis of the proposals submitted by 52 councils reveals that these towns considered increasing urbanised land by 272 million square metres, in order to build 718,000 homes for 2 million residents. In towns that today have 5,000 to 20,000 inhabitants, these new development plans would multiply the number of homes by four, the amount of urbanised land by five, and the number of residents by more than seven (Burriel de Orueta [14]). Most of these development plans were submitted in 2005, coinciding with the property boom, and continue to be processed, despite the property crisis and the notable surplus of homes, without any modifications to their expansion plans. This has also led to a number of legal disputes being filed against the processing of IAPs. In many cases, following requests by the local office of the State Government and the Júcar Basin Water 
Authority, in 2006 and 2007 the High Court of Justice in the Region of Valencia halted the construction of tens of thousands of homes in various towns in the region (La Nucía, Parcent, Cullera, Riba-roja, etc), as they lacked a favourable report from the water authority ensuring sufficient availability of water.

Land zoning policies must be accompanied by other measures, such as optimising existing resources by means of policies to ensure savings in irrigation and in urban and tourist settings. Waste water treated using advanced systems may help for agreements to be reached between irrigators and suppliers for transferring clean water, as per the Benidorm model. Commitments should also be made to implement measures to manage demand, in order to guarantee supply for the most socioeconomically important agricultural and urban uses. Similarly, as a result of the 2000/60/EC Water Framework Directive, a suitable policy of pricing and cost recovery is needed for each type of consumption, in order to encourage transfer contracts and public water banks as set out in Spain's Water Law. These measures should be based on containing current urban demands, given the growth models adopted, particularly with regard to clearly unsustainable residential models. Otherwise, any actions will only ever be insufficient. Measures aimed at improving the efficiency of urban and tourismbased supplies have been revealing. With regard to reducing distribution, significant progress has been made. The cities with the highest levels of consumption have attracted the interest of private companies specialising in the integral management of drinking water; however, major savings can still be made, particularly in small- and medium-sized towns (Saurí et al [15]). The management experience that companies of this type have explains how consumption trends have been contained in growing towns such as Benidorm and Alicante thanks to a better control of aspects such as leakages, undermetering and late payments, to the extent that unpaid bills now account for no more than $10 \%$ of the total. Good business management of drinking water has meant that rising demands can be contained; however, this has not led to a reduction in costs, given the high rate of urbanisation in the past decade, and with this the incessant rise of both permanent and seasonal populations. Limiting further urban sprawl should be a priority in the Region of Valencia, in accordance with regional laws that have come into effect in recent years.

\section{Acknowledgement}

This article is part of the research project "Models of land development and types of consumption of drinking water in residential tourist areas on the Alicante coastline" (CSO2009-12772-C03-03), funded by the Ministry of Science and Technology.

\section{References}

[1] Instituto Nacional de Estadística (INE), Contabilidad regional de España, 2008. Online http://www.ine.es/ 
[2] Generalitat Valenciana, Datos básicos del sector agrario valenciano, 2008. Online http://www.gva.es/jsp/portalgv.jsp?deliberate $=$ true

[3] Gil Olcina, A. \& Rico Amorós, A.M, El problema del agua en la Comunidad Valenciana. Generalitat Valenciana: Valencia, 2007.

[4] Juárez Sánchez Rubio, C, Indicadores hídricos de sostenibilidad y desarrollo turístico y residencial en la Costa Blanca (Alicante). Boletín de la $A G E$, (47), pp. 213-243, 2008.

[5] Navalón García, R., Agricultura y turismo en la franja costera de la Comunidad Valenciana, Fundación Bancaja: Valencia, 2001.

[6] Rico Amorós, A.M. \& Hernández Hernández, M., Ordenación del territorio, escasez de recursos hídricos, competencia de usos e intensificación de las demanda urbano-turísticas en la Comunidad Valenciana. Documents d'Anàlisi Geogràfica, (51), pp.79-109, 2008.

[7] Agencia Valenciana de Turismo, Oferta turística municipal y comarcal. 2008, Online, http://www.comunidad-valenciana.org/documentacion/ estudios/oferta.htm).

[8] Vera Rebollo, J.F., Casado Díaz, J.M. \& Ramón Rodríguez, A.B., Consideraciones sobre el impacto del Plan Hidrológico Nacional en el sector turístico de la provincia de Alicante (chapter 6). Repercusiones socioeconómicas del Plan Hidrológico Nacional en la provincia de Alicante, Fundación COEPA: Alicante, pp. 205-267, 2004.

[9] Ministerio de Fomento, Atlas estadístico de la vivienda. Madrid. 2004.

[10] Ministerio de Vivienda, Encuestas y estudios, 2009. Online http://www.mviv.es/

[11] Rico Amorós A.M. Olcina Cantos, J., Baños Castiñeira, C., Hernández Hernández, M. \& Torres Alfosea, F.J., Estudio piloto de análisis económico del uso del agua en la industria, usos recreativos y otros usos en la cuenca del Júcar, Ministerio de Medio Ambiente: Madrid, 2004.

[12] Tello, E., Dèficits hídrics o ciutats insostenibles? Primeres Jornades Catalanes per una Nova Cultura de l'Aigua, Barcelona, 2001.

[13] Blanquer Criado, D., Turismo residencial y urbanizaciones privadas: los servicios públicos de prestación obligatoria $\mathrm{y}$ alternativas a su incumplimiento por el ayuntamiento (chapter 3). Ordenación y gestión del territorio turístico, Tirant lo Blanch: Valencia, pp. 840-950, 2002.

[14] Burriel de Orueta, E., Los límites del planeamiento urbanístico municipal. Documents d'Analisi Geográfica, 54, pp.33-54, 2009.

[15] Saurí, D., Olcina, J. \& Rico, A., The March towards Privatisation? Urban Water Supply and Sanitation in Spain. Journal of Comparative Social Welfare, 23 (2), pp. 131-139, 2007. 